YAK 347.4

DOI https://doi.org/10.32837/chc.v0i35.181

Гуйван Петро Амитрович,

канАиАат юриАичних наук, заслужений юрист України, професор Полтавського інституту бізнесу

\title{
ПРАВОВА КОЛІЗІЯ МІЖ НАБУТТЯМ ПРАВА ВЛАСНОСТІ В МОМЕНТ ОТРИМАННЯ РЕЧІ ВІД НЕПОВНОВАЖНОГО ВІДЧУЖУВАЧА Й ВІНДИКАЦІЄЮ
}

Постановка проблеми. Українське цивільне законодавство цілеспрямовано запроваджує механізм реалізації права володіння чужою річчю і права на захист віА порушення такого володіння, в тому числі й віА власника. Так, нормативно врегульовано питання набуття власності піА час отримання речі віА неповноважного відчужувача (ст. 330 Цивільного кодексу України (Аалі - ЦКУ)) та за набувальною Аавністю (ст. 344 ЦКУ). При цьому в обох випадках визначальним є Аобросовісний статус окупанта, bona fides має бути присутня на час отримання майна. Інакше кажучи, набувач не повинен усвідомлювати факту незаконності відчуження. Аобросовісність володіння чужою річчю $€$ внутрішнім показником усвідомлення певного майнового стану самим суб'єктом. Уважаючи себе законним набувачем речі, пізнаючи соціальну цінність власної особистості, він водночас визнає автономію контрагента, виявляє повагу до нього. І якраз таким ось чином цей суб'єкт забезпечує міцність створеного ним матеріального зв'язку. Отже, поняття Аобросовісності $€$ виявом конформності щодо принципів справедливості, усвідомлених і сприйнятих особою на рівні індивідуальних ціннісних орієнтацій [1, с. 96-97].

Разом із тим національне законодавство, на жаль, не проводить чіткої межі між давнісним набуттям власності й отриманням цього права віАразу з прийняттям речі віА неповноважного відчужувача. Стаття 330 ЦКУ передбачає останню ситуацію за наявності в момент переходу майна повного пакету обмежень віндикації. Але к^ючовою вимогою Аля реалізації подібного механізму $€$ наявність доброї совісті набувача на час отри- мання ним товару. Позаяк ця конструкція сутнісно Ауже близька до іншої - набуття права власності в результаті тривалого віАкритого й безперервного володіння чужим майном, стає Аосить актуальним з'ясування співвідношення між Авома, зАавалося б, Аосить близьким за змістом матеріально-правовими механізмами набуття права власності: піА час купівлі речі в неповноважного відчужувача (ст. 330 ЦКУ) та за набувальною давністю (ст. 344 ЦКУ). Попри певну зовнішню схожість, вони все ж $є$ не однаковими за сутністю. Також вельми цікавим і недостатньо вивченим $€$ питання правової колізії між статичним правом власності неволодіючого власника та Аинамічним правом володіючого невласника. Традиційно в науці цивілістики прийнято вирішувати ії шляхом побудови віАповіАного захисного інструментарію - віндикації, з одного боку, і вінАикаційних обмежень - з іншого. Тож чи Аійсно чинний механізм правового захисту вказаних прав учасників відносин є алекватним, належним і дієвим?

Стан Аослідження теми. Питанням, пов'язаним із правовими інструментами отримання власності незаконним окупантом чужого майна, в Аоктрині присвячено праці таких учених, як М.А. Левитський, Г.Ф. Шершеневич, А.І. Мейєр, І.В. Аксюк, А.К. Бутовський, А.В. АожАєв, К.І. Скловський, Г.А. ГаАжиєв, Т.Ю. АрозАова, А.І. Авласевич, В.І. Цікало, В.П. Маковій та інші. у цих працях виказана різна правова оцінка Аосліджуваних нині особливостей набувних власницьких інститутів. Низка Аосить авторитетних учених-цивілістів указує на наявність виключного механізму отримання власності. Причому залежно віА правової обґрунтованості подібні 
виключні способи пов'язуються або з результатом спливу строку Аавнісного володіння або 3 іншим - Аобросовісним - придбанням речі віА неповноважного традента. При цьому вказані механізми представляються як взаємовик^ючні. Зокрема, вказується, що добросовісний набувач за вілмови власникові у віндикаційному Аомаганні зАатен отримати право власності тільки за Аавністю володіння, іншого способу не передбачено чинним законодавством [2]. Інакше кажучи, добросовісна особа, що отримала захист віА віндикації, продовжує володіти без титулу, незаконно й, аби стати власником, потребує набувальної Аавності [3, с. 253; 4, с. 69-70]. Інші АосліАники більш толерантно оцінюють правовий механізм набуття власності в момент Аобросовісного отримання речі віА неповноважного продавця, але при цьому вони також задіюють інститут давності набувальної, надаючи їй нульової тривалості (моментальна набувальна Аавність) [5, с. 138]. Аослідження цього питання та напрацювання практичних рекомендацій щодо реальної природи кожного зі способів набуття власності становить мету статті.

ВикиаА основного матеріалу АосліАження з повним обґрунтуванням отриманих наукових результатів. У цьому контексті ми вважаємо вказані вище правові підходи не зовсім виваженими. Насправді, не можна не бачити різної юридичної сутності набуття права власності Аобросовісним набувачем віА неповноважного віАчужувача та в режимі набувальної Аавності. Попри те що Аосягається, принаймні зовнішньо, оАнаковий результат, задіюються віАмінні правові й соціальні стрижні. Аавність як основа подальшої власності реалізує мовчазне погодження попереднього носія права на уступку іншій особі [6, с. 28], це відбувається за згоди власника або без такої, але його пасивність протягом установленого законом періоду вільно чи невільно має юридичне значення. Натомість за наявності обставин, указаних у ч. 1 ст. 388 ЦКУ, можливість особи, що втратила річ, повернути ії припиняється якраз не з огляду на тривале користування іншим суб'єктом, а саме у зв'язку з набуттям останнім права власності. І хай би як не тлумачили окремі досліАники цю ситуацію, нині застосування правила статті 330 ЦКУ має бути оАнозначним: Аобросовісний набувач майна віА неповноважного віАчужувача стає його власником саме в момент передачі речі. Bona fides тут має вирішальне значення: сторона, уклавши договір з особою, котра має лише видимість правомочності, захищена не тому, що їй передалося відповідне право, а всупереч цьому [7, с. 273].

Сенс і значення придбання права власності за Аавністю володіння полягають у тому, що власник утратив інтерес до права й не вимагає його зАійснення [8, с. 125]. У разі ж із добросовісним набуттям особа, що продовжує вважати себе власником, усіляко намагається повернути річ, але закон їй такої можливості не надає. Тож між Авома вказаними явищами: набуттям власності за Аавністю володіння та добросовісним набуттям речі віА неповноважного відчужувача - існує принципова різниця. Варто визнати цілком правильним твердження В.А. Рахміловича: набувальна Аавність застосовується, зокрема, у тих випалках, коли річ могла бути витребувана в Аобросовісного набувача, коли ж майно не може бути витребуване, немає місця Аля набувальної Аавності [9, с. $127-128]$.

I $з$ урахуванням цього сфера застосування набувальної Аавності Аля Аобросовісних набувачів насправді значно звужується: за чинним українським законодавством, такі суб'єкти стануть власниками утримуваного майна тільки за наявності складного фактичного складу: 1) річ отримана безоплатно або свого часу вибула віА власника з дефектом волі останнього; 2) власник протягом позовної Аавності не витребував річ із Аобросовісного незаконного володіння. Коли ж подібні обставини віАсутні, мова йде про наявність установлених законом заперечень проти віндикації, тому власність набувається Аобросовісним незаконним окупантом відразу в момент отримання речі.

Отже, очевидною $є$ теза, що перехіА права власності віА неповноважного відчужувача до Аобросовісного набувача за наявності передбачених у ст. 330 ЦКУ обставин відбувається саме в момент переходу володіння. Уважаємо подібний підхіА аАекватним і єАино правильним. У Аоктрині нині така позиція має певну, хоча далеко не всезагальну підтримку. Прихильники її вважають, що перехіА права власності віА попереднього власника Ао незаконного Аобросовісного набувача відбувається незалежно віА бажання власника та учасників відчуження за наявності повного набору елементів юридичного складу. Елементи цього складу мають окреме юридичне значення, лише їх сукупність викликає віАповіАний правовий ефект. Ао цього переліку входять такі юриАичні факти, як укладення між неуповноваженим відчужувачем і набувачем угоди про перехіА 
права власності; набувач є Аобросовісний; Аоговір має відплатний характер; відбулася фактична передача майна набувачеві; річ не вилучена з обороту та ії обігоздатність не обмежена; річ вибула з володіння власника або першого титульного володільця не поза їхньою волею [9, с. 132]. Спрямованість закону в цьому випадку полягає в захисті інтересів Аобросовісного віАплатного набувача, який на основі комплексного юридичного складу віАразу стає власником придбаного майна. Саме тому річ віндикувати неможливо, тому що набувач став її власником.

Цей правовий наслідок - отримання набувачем власності - має місце незалежно віА волі попереднього власника й усвідомлення ним факту незаконного відчуження. Власне, наявність обставин, які формують зміст заперечень проти віндикації, має презумуватися, коли в певний Момент У хоАі РОзгАяАУ віАПовіАНоГо вінАикаційного позову їх наявність буде спростована, у судовому порядку буде встановлено віАсутність набутого права власності шляхом нетитульного віАчуження речі Аобросовісній особі. В іншому разі подібний набувач має вважатися власником. ТоАі коло Аобросовісних Аавнісних володільців, які не набули власності, значно скорочується. Ао нього належать мише особи, котрі отримали майно віА неповноважного відчужувача безоп^атно, вважаючи останнього власником, тобто Аобросовісно помиляючись у цьому стосунку. Інші категорії Аобросовісних набувачів Аля їх кваліфікації як Аавнісних володільців відверто не підхоАять, аАже особа, що отримала віА нетитульного традента річ, яка свого часу вибула віА власника поза його волею (шляхом обману, вкрадена або вийшла з володіння з іншим пороком волі), не знаючи про подібні Аефекти, повністю охоплюється поняттям Аобросовісності, викладеним у правилі ст. 330 ЦКУ, з віАповіАним насліАком - визнанням права власності в нього віА часу окупації, звісно, піА загрозою можливого спростування цього факту у вінАикаційному процесі в судовому поряаку.

Отже, класичний віндикаційний позов як процесуальна вимога безперечного неволодіючого власника Ао безперечного володіючого Аобросовісного окупанта можливий тімьки в разі безвіАплатного отримання останнім майна. У всіх інших випадках у разі преА'явлення подібної вимоги до суду про відібрання речі (з формального погляду це Аомагання не можна називати віндикацією, бо питання про наявність титулу саме в позивача ще піАлягає встановленню) спір перетворюється в установлення права власності на спірну річ. Якщо виявиться, що у відповідача є весь комплект передбачених законом заперечень проти вимог про витребування майна (їх у науці звуть запереченнями проти віндикації), буде встановлено, що реальним власником як на момент неправомірного відчуження, так і на час розгляду судової справи є Аобросовісний набувач. Тобто його право буде захищене шляхом відмови в позові особі, яка пред'явила Аомагання. І зазначений наслідок настане не тому, що відповідач застосував наявні в нього заперечення проти віндикації (аАже за визначенням віндикація - це судова вимога власника до невласника), а тому, що позивач, будучи свого часу за законом позбавлений титулу, не має права на захист. У свою чергу, віАповідач $є$ власником і має право на захист свого права не лише віА колишнього власника, а й віА інших осіб, не наАілених віАповіАним титулом.

Коли піА час РозгляАУ ПОАібноГО ПозОвУ виявиться, що відповідач - Аобросовісний незаконний набувач майна - не має повного комплекту передбачених законом заперечень проти вимог, буде встановлено низку інших правових наслідків. По-перше, встановлюється віАсутність законодавчої презумпції про набуття права власності в момент передачі речі. По-друге, процес набуває ознак віндикації, а володілець кваліфікується як Аавнісний Аобросовісний володілець. Нарешті, по-третє, позивач, право власності якого, а отже, і можливість його судового захисту піАтверАжується саме в цьому ж процесі, може витребувати своє майно. Але такий насліАок задоволення його вимоги настає мише тоді, коли не спливла позовна Аавність за віАповіАним Аомаганням, про що заявлено окупантом. В іншому разі, навіть будучи уповноваженим на позов, власник отримує процесуальне рішення про віАмову. І незаконний окупант, кваліфікований у межах цього процесу як Аавнісний володілець віА часу отримання майна, продовжуватиме подальше володіння чужим майном, Аопоки не набудеться повний комплект чинників Аля переходу такого володіння у право власності за набувальною Аавністю.

^ише в подібний спосіб ми уникнемо звинувачень багатьох апологетів теорії про порушення у віндикаційному розгляді права або власника, або незаконного набувача. ВіАходячи піА час вирішення спору віА класичного, але, як бачимо, неправильного за сутністю питання про наявність заперечень проти віндикації в цьому випаАку і ставлячи акценти на наявності чи віАсутності 


\section{6 回回回回回回回回回回回回回回回回回回回回 Випуск 35}

самого охоронюваного законом права на позов, ми практично зміщуємо преАмет розгляАу в площину спору про право. Фактично піляягає вирішенню позадоговірний спір осіб про констатацію факту належності власності на спірне майно, не пов'язане формально з конкретними вимогами про повернення речі чи усунення перешкоА у його утриманні. Тому необхіАно усвіАомлювати якраз первинну мету, на Аосягнення якої спрямовано вказаний спосіб захисту. Саме це питання вирішується насампереА, а вже потім настає резолюція про захист наявного права шляхом задоволення позову чи його віАхилення. При цьому фактичне перебування майна в позивача чи відповідача не має вирішального значення Аля вирішення питання про захист. У будь-якому разі має бути захищене мише те право, яке буде встановлене в процесі вирішення питання про визнання. Отже, як бачимо, класичне поняття віндикації або використовується в нашій Аоктрині неправильно, порушуючи речове право власності незаконного добросовісного набувача, передбачене ст. 330 ЦКУ, або ж утратило свою реальну сутність з урахуванням наведених вище його реальних ознак.

Але повернемося до питання, яке поставлене в заголовок праці, щодо вирішення наявної колізії між статикою та Аинамікою матеріально-речових відносин у цивільному праві. Наведене вище Аавнісне володіння навіть після рішення суду про відмову в заАоволенні віндикаційного позову через сплив позовної Аавності жодним чином не трансформує право Аавнісного володіння у власність. Воно продовжується Ао настання обставин, передбачених у ст. 344 ЦКУ. Це може тривати Аосить Аовго, і володілець весь час перебуватиме в подібному статусі. Більше того, право власності може взагалі не набутися, принаймні протягом якого завгодно Аовгого часу: володіння Ао закінчення встановленого законом строку Аавності може перериватися, окупант - змінитися. Тобто починається новий набувальний строк, і так може тривати нескінченно Аовго. При цьому володіння не забезпечене якимось правовим титулом. у свою чергу, особа, яка отримала судову віАмову у витребуванні належної їй речі, не позбавлена статусу власника, хоча й неволодіючого. у нього є правовий титул. Але чи може суб'єкт отримати якийсь практичний резон із цього, реалізувавши його? Питання не таке вже й просте. Скажімо, власник може проявити самоуправство й самостійно відібрати майно в Аобросовісного Аавнісного володільця. Власне, за таких обста- вин він опиниться поза межами права, такі дії будуть незаконними. Але виникає питання: а як саме Аавнісний володілець може захистити своє володіння, що неправомірно припинене. Крім морального боку справи, коли суд повинен буде захищати незаконного окупанта проти реального власника, з'являється проблема правового обґрунтування подібної судової вимоги, аАже, суворо кажучи, правило ч. 3 ст. 344 ЦКУ, яке видається Аосить прогресивним та адекватним, насправді стосується ^ише одного аспекту можмивих ситуаційних питань - неправомірного вилучення майна його власником віА особи, що свого часу набула повноважень Аавнісного володільця в разі своєчасного неповернення речі. Указане правило безпосередньо не поширюється на випаАки Аобросовісного заволодіння майном у поряАку користування ним Аля Аавності. Уважаємо це значним неАоліком чинного цивільного законодавства, який необхінно негайно усунути, надавши вказаному правилу загального, а не мокального характеру піА час реалізації будь-яких механізмів Аавнісного набуття власності. Але навіть цього нині вже зама^о. На часі правове визначення цілої системи володільницького посесорного захисту.

Водночас іншим головним чинником у цьому процесі $€$ забезпечення надійного балансу в захисті прав власника й давнісного володільця. Зокрема, заАля тої ж стабільності матеріального обороту має гарантуватися й адекватний захист права власності. Розглядаючи ситуацію, коли власник, пропустивши позовну Аавність за віндикаційними вимогами, не перестає мати правовий титул, але позбавляється можливості законно претендувати на своє майно, маємо сказати, що це правило на повинно мати абсолютного характеру. Інакше просто не зрозумілою є принципова наявність титулу, який навіки втратив свою зАатність Ао реалізації. Власне, за загальними законами природи, неможливе існування якогось явища, яке позбавлене реальної властивості бути здійсненим. Тож, відповіАно до правил матеріального світу, мусить рухатися й регульований конкретними віАносинами в суспільстві правовий механізм.

Має бути чітко прописане правило, за яким у разі припинення Аавнісного набувального волоАіння незаконним окупантом починається таке ж Аавнісне володіння з боку нового набувача, якщо за своєю сутністю воно відповідає правилам ст. 344 ЦКУ. А^е прикметно, що за подібних обставин відбудеться нове порушення права неволоді- 
ючого власника. Це логічно. За загальним поряАком речово-правової регламентації, порушенням права власності, що полягає в позбавленні правомочності володіння, $€$ не вилучення майна, а саме незаконне утримання його. ВіАповіАно, порушником речового права володіння буде не та особа, котра річ вилучила віА власника поза його волею, а якраз незаконний набувач, навіть попри його Аобросовісність. Отже, незалежно віА того, наявна Аобра совість у нового окупанта чи ні, $€$ в новому володінні давнісний характер чи ні, у момент чергового заволодіння віАбувається нове порушення права власності особи, яка продовжує володіти власницьким титулом. Це правопорушення, хоча й має той же преАмет, що раніше, містить новий суб'єктний склаА. Тож саме таке за змістом порушення віАбулося вперше. Отже, віАповіАно до чинного темпорального циві^ьного правового інституту позовної Аавності, перебіг нового строку за вимогами про витребування речі віА незаконного волоАільця починається віА Аня, коли особа Аовідалася про факт порушення й особу порушника (ст. 261 ЦКУ). І право власності, яке, зАавалося б, утратило свою зАатність Ао зАійснення, отримує нову силу. Інша річ, що піА час його віндикаційного захисту у власника можуть виникнути Аодаткові проблеми, пов'язані з необхідністю спростування наявних у нового володільця заперечень проти віндикації, що випливають із фактичних обставин нової окупації.
Висновки з АосліАження та перспективи подальших розвіАоК у цьому напрямі. 3 викладеного можемо резюмувати таке. 3 метою забезпечення більш раціональної та ефективної динаміки матеріального обороту цивільне законодавство визнає існування безтитульного володіння чужою річчю й певним чином намагається забезпечити його захист. 3 огляду на це, можемо вести мову про існування суб'єктивного матеріального права - права на незаконне володіння чужим майном. Більше того, за певних обставин добросовісний незаконний володілець отримує право власності на таке майно. Саме із цього погляду варто розглядати положення Кодексу про отримання власності в момент передачі речі віА неповноважного традента та про набувальну Аавність. За цими правилами, Аобросовісний набувач стає або власником майна віАразу після отримання речі (ст. 330 ЦКУ), або Аавнісним володільцем (ч. 1 ст. 344 ЦКУ). В останньому випадку він, хоча й не вправі заперечувати проти віндикації, за певних обставин (віАмова в позові у зв'язку зі спливом позовної давності за вимогою про витребування речі, непред'явлення такого позову взагалі, закінчення строку Аії права на Аавнісне волоАіння) може отримати право власності на чуже майно. Коли ж у набувача існує на момент отримання майна повний пакет заперечень проти віндикації, він стає власником віА часу передачі. I наявність подібного пакету має презумуватися.

\section{NITEPATYPA:}

1. Дождев Д.В. Добросовестность (bona fides) как правовой принцип. Политико-правовые иенности: история и современность / под ред. В.С. Нерсесянца. Москва : Едиториал УРСС, 2000. С. 96-128.

2. Авласевич А.И. Проблемы приобретения права собственности от неуправомоченного отчуждателя, владения и владельческой защиты. URL: http://www.ibil.ru/index.php?type=review\&area=1\&p=articles\&id=708.

3. Скловский К.И. Собственность в гражданском праве : учебно-практическое пособие. Москва : Дело, 1999. 512 с.

4. Аксюк И.В. Добросовестность приобретения как основание как основание возникновения права собственности на недвижимость. Журнал российского права. 2007. № 3. С. 67-72.

5. Морандьер Жулио де ла. Гражданское право Франции / перевод с французского Е.А. Флейшиц. Москва, 1960. Т. 2. 728 с.

6. Попович П.В. Приобретательная давность по русскому и остзейскому гражданскому праву равно по проекту гражданского уложения. Варшава : Тип. Варшавского учебного округа, 1913. 252 с.

7. Эннекцерус Л. Курс германского гражданского права / пер с нем. Москва, 1949. Т. 1. Полутом 1 / под ред. И.Б. Новицкого. $483 \mathrm{c.}$

8. Бубнов М.Ю. Приобретательная давность как основание приобретения права собственности : дисс. .... канд. юрид. наук : 12.00.03. Рязань, 2003. 174 с.

9. Рахмилович В.А. О праве собственности на вещь, отчужденную неуправомоченным лицом добросовестному приобретателю (к вопросу о приобретении права от неуправомоченного лица). Проблемы современного гражданского права : сборник статей / отв. ред. В.Н. Литовкин, В.А. Рахмилович. Москва : Городец, 2000. С. 126-144.

\section{Гуйван Петро Амитрович \\ ПРАВОВА КОКІЗІЯ МІЖНАБУТТЯМ ПРАВА ВААСНОСТІ В МОМЕНТ ОТРИМАННЯ РЕЧІ ВІАНЕПОВНОВАЖНОГО ВІАЧУЖУВАЧА Й ВІНАИКАЦІЮ}

Стаття присвячена вивченню актуального питання співвіАношення правових механізмів переходу права власності Ао незаконного Аобросовісного набувача в момент отримання ним речі віА неповноважного віАчужувача та в порядку реалізації механізму набувальної давності. Автор праці вважає, що сучасна цивілістика не 
зовсім правильно оперує таким поняттям, як “способи заперечень проти віндикації», вимушено перетворюючи матеріальний речовий захист власності у фактичний спір про наявність чи віАсутність права. Тому в статті розглянуто аспекти правової колізії між статичним правом власності неволодіючого власника й динамічним правом володіючого невласника. Установлено, що за наявності у володільця заперечень проти віндикації в позові має бути відмовлено не завАяки їм, а саме у зв'язку з віАсутністю в позивача права, яке він міг би захистити за Аопомогою вінаикації.

Киючові слова: набувальна Аавність, перехіА власності, Аобросовісний набувач, віндикація.

\section{Гуйван Петр Амитриевич \\ ПРАВОВАЯ КОМИИЗЯ МЕЖАУ ПРИОБРЕТЕНИЕМ ПРАВА СОБСТВЕННОСТИ В МОМЕНТ ПОЛУЧЕНИЯ ВЕЩИ ОТ НЕПОЛНОМОЧНОГО ОТЧУЖААТЕАЯ И ВИНАИКАЦИЕЙ}

Статья посвящена изучению актуального вопроса соотношения правовых механизмов перехода права собственности к незаконному добросовестному приобретателю в момент получения им вещи от неполномочного отчуждателя и в порядке реализации механизма приобретательной Аавности. Автор труда считает, что современная цивилистика не совсем правильно оперирует таким понятием, как “способы возражения против винАикации", вынужденно превращая материальную вещную защиту собственности в фактический спор о наличии или отсутствии права. Поэтому в работе рассмотрены аспекты правовой колмизии между статическим правом собственности невладеющего собственника и динамичным правом владеющего несобственника. Установлено, что при наличии у владельца возражений против виндикации в иске Аолжно быть отказано не благодаря им, а именно в связи с отсутствием у истца права, которое он мог бы защитить с помощью винаикации.

Киючевые слова: приобретательная Аавность, перехоА собственности, Аобросовестный приобретатель, винАикация.

\section{Guyvan Petro \\ LEGAL CONFLICT BETWEEN THE ACQUISITION OF PROPERTY RIGHTS AT THE TIME OF RECEIPT OF THE THING FROM AN UNAUTHORIZED ALIENATOR AND VINDICATION}

The article is devoted to the study of the current issue of the correlation of legal mechanisms of transfer of ownership to an illegal bona fide purchaser at the time of receiving the thing from an unauthorized alienator and in the manner of realization of the mechanism of prescription. It is noted that this issue is one of the most debatable in the field of modern civilistic theory. The traditional safeguard mechanism in the event of a violation of such an element of property rights as holding one's own property, which is traditionally mediated by the rules vindication. The author of the paper believes that modern civilistics does not quite properly operate such concepts as "ways of objection to vindication", forcing the material protection of property into a factual dispute about the presence or absence of law. Therefore, aspects of the legal conflict between the static ownership of the non-controlling owner and the dynamic right of the occupying occupier are considered.

It is established that national legislation, unfortunately, does not draw a clear boundary between the prescriptive acquisition of property and the acquisition of this right immediately with the acceptance of a thing by an unauthorized alienator. Therefore, in this paper it is found that the meaning and value of the acquisition of ownership over the prescription of holdership is that the owner has lost interest in the right and does not require its implementation, whereas in the case of good faith acquisition of a person who continues to consider himself the owner in every possible way trying to turn things around, but the law does not give him that opportunity. Thus, the statute of limitations applies in cases where a thing could be claimed from a bona fide purchaser, when the property cannot be claimed - there is no place for a statute of limitations. A bona fide non-titular acquirer will become the owner of the retained property only when the thing is received free of charge, or when it has at one time disposed of the owner with a defect in the latter's will, or if the owner did not claim the thing from good faith unlawful possession during the statute of limitations. When such circumstances are absent, it is a question of the presence of legal objections against the hijacking, so the property is acquired by a conscientious illegal occupier right at the moment of receiving the thing. Thus, the classic content of a vindication claim as a way of protecting a non-possessive owner narrows to a small number of circumstances: claiming a thing from a person who has received property in good faith for free or with a defect in the owner's will. In other cases, such solicitation is reduced to a dispute over a law that contradicts the classical essence of a vindication. After all, if the owner has objections to the vindication, the claim should be rejected not because of them, but in connection with the lack of the claimant's rights that he could protect through the vindication.

Key words: acquisition statute of limitations, ownership transfer, bona fide acquirer, vindication. 